\title{
Analytical Standards of Amrtadi Churna: A Classical Ayurvedic Formulation
}

\author{
SANGEETA MUKHI, A. BOSE* A. RAY ${ }^{1}$ AND P. K. SWAIN²
}

Department of Pharmaceutical Analysis and Quality Assurance, School of Pharmaceutical Sciences, ${ }^{1}$ Centre of Biotechnology, Siksha 'O' Anusandhan University, Bhubaneswar-751 030, 2State Drug Testing \& Research Laboratory (ISM), Government of Odisha, Government Ayurvedic Hospital Campus, BJB-Nagar, Bhubaneswar-751 014, India

\author{
Sangeeta, et al.: Analytical Standards of Amrtadi Churna
}

\begin{abstract}
The present investigation was carried out to characterise the Ayurvedic preparation, Amrtadi churna, a polyherbal formulation comprising of three ingredients, on the basis of the pharmacognostic, physicochemical, pharmaceutical, microbiological, toxicological, spectroscopic and chromatographic parameters to confirm its identity, quality and purity. The results obtained in this evaluation demonstrated the potential to identify each and every ingredient in Amrtadi churna. The parameters documented in this paper could be used for the preparation of the monograph on quality standards for Amrtadi churna to maintain its batch-to-batch consistency. This document could also be utilised for Fourier transform infrared spectroscopy and high performance thin layer chromatography based rapid authentication for the formulation.
\end{abstract}

Key words: Amrtadi churna, pharmacognostic, toxicological, chromatography, thermogravimetry

According to World Health Organization (WHO) traditional, complementary, alternative, or nonconventional medicines are used by $70-95 \%$ of global population particularly in developing countries for their healthcare ${ }^{[1]}$. Moreover, the use of herbal medicines has increased remarkably in line with the global trend of people returning to natural therapies ${ }^{[2]}$. The growing use of botanicals by the public is forcing moves to assess the health claims of these agents and to develop standards of quality and manufacture.

Standardization of herbal medicines is the process of prescribing a set of standards or inherent characteristics, constant parameters, definitive qualitative and quantitative values that carry an assurance of quality, efficacy, safety and reproducibility. Herbal product cannot be considered scientifically valid if the drug tested has not been authenticated and characterised in order to ensure reproducibility in the manufacturing of the product. Moreover, many dangerous and lethal side effects have recently been reported, including direct toxic effects, allergic reactions, effects from contaminants and interactions with herbal drugs ${ }^{[2]}$. In view of the above, standardization is an important step for the establishment of a consistent biological activity, a consistent chemical profile, or simply, a quality

*Address for correspondence

E-mail: anindyabose_in@yahoo.com

March-April 2017 assurance program for production and manufacturing of an herbal drug ${ }^{[3]}$.

The Indian system of medicine, mainly comprising of Ayurveda, Siddha and Unani, is one of the oldest holistic management system with thoroughly documented remedies. Ayurveda, a part of the cultural heritage of India, is widely respected for its uniqueness and global acceptance as it offers natural ways to treat diseases and promote healthcare ${ }^{[4]}$. Unfortunately, standardization and quality control have remained grey areas in the preparation of Ayurvedic medicines. Till date, most of the Ayurvedic formulations are lacking in their defined quality control parameters and method of evaluation $^{[5]}$.

Amrtadi churna, an Ayurvedic polyherbal churna (fine powder) formulation, is prescribed by the Ayurvedic physician for treating conditions such as hyperacidity (one type of pitta dosha in Ayurveda) and also acts as an immunomodulator ${ }^{[1]}$. It contains three ingredients,

This is an open access article distributed under the terms of the Creative Commons Attribution-NonCommercial-ShareAlike 3.0 License, which allows others to remix, tweak, and build upon the work non-commercially, as long as the author is credited and the new creations are licensed under the identical terms

Accepted 08 March 2017

Revised 12 December 2016

Received 27 August 2016

Indian J Pharm Sci 2017;79(2):227-240 
Gokshur (Tribulus terrestris), Amalaki (Emblica officinalis) and Guduchi (Tinospora cordifolia) mixed in equal proportion (Table 1). To the best of our knowledge, there is no published report on the scientific analysis of Amrtadi churna till date, hence the present work was carried out to develop the quality control parameters of Amrtadi churna to confirm its identity, quality and purity.

This work dealt with detailed evaluation of Amrtadi churna following the guidelines prescribed by Ayurvedic Pharmacopoeia of India (API). Standardization guidelines provided by the WHO, European Agency for Evaluation of Medicinal Products (EMEA) and United States Pharmacopoeia (USP) have also been considered. As part of the procedure, the churna was tested for relevant physical, chemical and analytical parameters for its safety and consistent efficacy through quality control measures ${ }^{[6-8]}$.

\section{MATERIALS AND METHODS}

All three ingredients of Amrtadi churna were procured from the local market of Bhubaneswar, Odisha, India and were authenticated in the Department of Botany, State Drug Testing and Research Laboratory (ISM), Bhubaneswar, Odisha, India. Voucher specimens of these ingredients were deposited in the Department of Pharmacognosy, State Drug Testing and Research Laboratory (ISM) for future reference.

Three batches of Amrtadi churna, AMC-I, AMC-II and AMC-III were prepared as per the standard method describe in the Ayurvedic formulary of India. As per the literature, all the ingredients were shade dried and powdered separately, passed through $80 \#$ sieve and then mixed together in required proportions to get uniformly blended churna ${ }^{[9]}$.

\section{Determination of foreign matter and organoleptic evaluation:}

About $100 \mathrm{~g}$ of the sample was spread out as a thin layer. Foreign matter was detected by inspection with the unaided eye or by the use of a magnifying lens (6x), separated, weighed and the percent foreign matter was calculated ${ }^{[10]}$. Organoleptic characters like colour, odour, taste, appearance and texture of the ingredients

\section{TABLE 1: COMPOSITION OF AMRTADI CHURNA}

\begin{tabular}{cccc}
\hline $\begin{array}{c}\text { Sanskrit } \\
\text { name }\end{array}$ & Scientific name & Part used & Quantity \\
\hline Gokshur & Tribulus terrestris & Dried fruit & 1 part \\
Amalaki & Emblica officinalis & Dried Pericarp & 1 part \\
Guduchi & Tinospora cordifolia & Dried stem & 1 part \\
\hline
\end{tabular}

and formulation samples were evaluated using a reported method ${ }^{[11]}$.

\section{Fluorescence analysis and study of microscopic characteristics:}

Fluorescence characters of powdered materials in different standard reagent solutions in the ordinary visible light and ultraviolet light (both long $365 \mathrm{~nm}$ and short $254 \mathrm{~nm}$ wavelengths) were observed ${ }^{[12]}$. Five $\mathrm{mg}$ of the sieved (80\#) powder samples (churna and ingredients) were taken and washed with plain water. Then the samples were treated separately with iodine, chloral hydrate, pholorglucinol or potassium iodide; a drop of glycerine was added and mounted. The powder sample characters were then observed by a Carl Zeiss binocular microscope attached with a camera according to the standard method ${ }^{[13,14]}$.

\section{Physicochemical investigation and flow properties:}

Different physicochemical investigations of the churna were carried out on all the three batches using standard pharmacopoeial methods, including determination of alcohol soluble extractives, water soluble extractives, total ash, acid insoluble ash, loss on drying and $\mathrm{pH}$ determinations ${ }^{[15,16]}$. Flowability parameters like bulk density, tap density, angle of repose, Hausner's ratio and Carr's index were determined and expressed as an average representing the three batches of churna formulation $^{[17]}$.

\section{Qualitative phytochemical investigation and heavy metal analysis:}

Comparative qualitative chemical tests were carried out for Amrtadi churna and its ingredients on their different extracts of various polarities. These phytochemical screening included tests for alkaloids, tannins, steroid, glycoside, flavonoids, saponins, carbohydrates, terpenoids and proteins ${ }^{[18]}$. Heavy metal analysis was performed using Perkin Elmer AAS-200 instrument. As per the protocol, sample digestion was carried out by multi-acid digestion system for lead $(\mathrm{Pb})$, cadmium $(\mathrm{Cd})$, copper $(\mathrm{Cu})$, zinc $(\mathrm{Zn})$, nickel $(\mathrm{Ni})$ and chromium $(\mathrm{Cr})^{[19]}$. After completion of the digestion process, the filtered samples were analysed by Atomic Absorption Spectrometer $(\mathrm{AAS})^{[20]}$. However, being volatile, mercury ( $\mathrm{Hg}$ ) and arsenic (As) were digested using nitric acid-hydrochloric acid-potassium permanganate system before analysis ${ }^{[21]}$. The mercury vapour atomization (MVA) and hybrid vapour generation (HVG) attachments were utilised for AAS analysis of $\mathrm{Hg}$ and $\mathrm{As}$, respectively. The standards of $\mathrm{Pb}, \mathrm{Cd}$, $\mathrm{As}$, 
$\mathrm{Hg}, \mathrm{Cu}, \mathrm{Zn}, \mathrm{Ni}$ and $\mathrm{Cr}$ were purchased from Merck, Germany and utilised for development of the respective calibration curves for these metals ${ }^{[22]}$.

\section{Microbial limit test:}

Microbial analysis was carried out as per standard procedure mentioned in API. It included total bacterial count, total fungal count, presence of pathogens like Escherichia coli, Salmonella ebony, Pseudomonas aeruginosa and Staphylococcus aureus ${ }^{[23]}$.

\section{Pesticide residue study:}

The residues of pesticide of organochlorine, organophosphorous and pyrethroids classes were analysed using an Agilent 7000 Triple Quad GC/MS system equipped with a multimode inlet (MMI) using a DB-5 $(30 \mathrm{~m} \times 0.25 \mathrm{~mm} \times 0.25 \mu \mathrm{m})$ capillary column. The samples for analysis were prepared by the QuEChERS method $^{[24]}$. As per the standard study protocol, the GC oven temperature was programmed for linear increase from $50^{\circ}(1 \mathrm{~min}$ hold $)$ to $130^{\circ}$ at $10^{\circ} / \mathrm{min}, 130-250^{\circ}$ at $5^{\circ} / \mathrm{min}$ and then $250-300^{\circ}$, at $10^{\circ} / \mathrm{min}$. The injector temperature was $270^{\circ}$, with a split $40: 1$ and helium carrier gas at $1.1 \mathrm{ml} / \mathrm{min}$ flow. The mass spectrometric detector was operated in the GC-MS/MS mode with $70 \mathrm{eV}$ ionization energy, ion source temperature at $230^{\circ}$ and the quadruple mass detector at $150^{\circ}$. Internal standards of pp'DDT and chlorpyrifos were procured from Sigma Aldrich were utilised ${ }^{[25]}$. The list of pesticides tested in Amrtadi churna was listed in Table 2.

\section{Aflatoxin determination:}

The sample preparation was carried out by immunoaffinity column liquid chromatography as per the reported literature ${ }^{[26]}$. Aflatoxins were determined by HPLC analysis by Waters Alliance 2695 HPLC instrument using a Luna C18 column (Phenomenex) of dimensions $4.6 \times 150 \mathrm{~mm} \times 5 \mu$ coupled with a Waters 2475 fluorescence detector containing Cobra cell. In this method, $40 \mu \mathrm{l}$ of the samples were injected into the HPLC column heated at $40^{\circ}$. The mobile phase was taken as water:methanol solution $(60: 40, \mathrm{v} / \mathrm{v})$ with 119 mg of potassium bromide and $350 \mu 1$ of $4 \mathrm{M}$ nitric acid were added to the 11 of mobile phase for post column electrochemical derivatization of fluorescence detector. The flow rate was kept at $1 \mathrm{ml} / \mathrm{min}$ with a total runtime of $20 \mathrm{~min}$ where the retention times were found to be $7.5,9.38,11.44$ and 14.5 min for aflatoxins G2, G1, B2 and B1, respectively. The excitation wavelength and the emission wavelength for fluorescent detection were set at 362 and $455 \mathrm{~nm}$, respectively. The calibration standards were procured from Sigma Aldrich ${ }^{[27]}$.

\section{Fourier transforms infrared (FTIR) spectrophotometric profiling:}

FTIR profiling spectra of all three batches of Amrtadi churna were collected in the range of $4000-400 \mathrm{~cm}^{-1}$ using a Jasco FTIR spectrophotometer (model 4100). The freeze dried methanol extract of Amrtadi churna was mixed with $\mathrm{KBr}$ (FTIR grade) at a ratio of 1:100 and ground to fine powder and compressed into a pellet. The pellet was immediately placed in the sample holder of the FTIR and the spectrum was recorded as an average of eight scans.

\section{Thin layer chromatography (TLC) analysis:}

Accurately weighed $1 \mathrm{~g}$ of samples of the churna and its ingredients were separately dissolved in $20 \mathrm{ml}$ methanol and refluxed on a water bath at $90-100^{\circ}$ for $15 \mathrm{~min}$. They were filtered and evaporated up to $5 \mathrm{ml}$ in porcelain dish and taken for TLC profiling. Solvent systems consisting of toluene, chloroform, acetone, ethyl acetate, formic acid in the ratio of $3: 3: 2: 2: 0.5$ $(\mathrm{v} / \mathrm{v})$ and $4: 3: 2: 1: 0.5$, which gave the best separation through trial and error, were used for developing the TLC plates. Methanol extracts were applied on $0.2 \mathrm{~mm}$ thick precoated Silica Gel $60 \mathrm{~F}_{254}$ plates (Merck KGaA) and developed in the above mentioned solvent system.

\section{TABLE 2: LIST OF PESTICIDE RESIDUES TESTED IN AMRTADI CHURNA}

\begin{tabular}{|c|c|}
\hline Pesticide class & Compounds tested \\
\hline $\begin{array}{l}\text { Organochlorine } \\
\text { pesticides }\end{array}$ & $\begin{array}{l}\text { Butachlor; a-HCH; B-HCH; } \mathrm{Y}^{-\mathrm{HCH}} \text { (Lindane); } \delta \text {-HCH; O, P'-DDT; P, P'-DDT; O, P'-DDE; P, P'-DDE; } \\
\text { O, P'-DDD; P, P'-DDD; a-endosulfan; B-endosulfan; endosulfan sulphate; aldrin; dieldrin; endrin; } \\
\text { endrin aldehyde; endrin ketone; cis-chlordane; trans-chlordane; heptachlor; heptachlor epoxide; } \\
\text { methoxychlor; dicofol; alachlor; chlorthalonil; chlorobenzilate; dichlofluanid and vinclozolin }\end{array}$ \\
\hline $\begin{array}{l}\text { Organophos } \\
\text { pesticides }\end{array}$ & $\begin{array}{l}\text { Acephate; dichlorvos; ethion; fenitrothion; methamidophos; phosalone; profenofos; quinalphos; } \\
\text { triazophos; chlorfenvinphos; chlorpyriphos; chlorpyriphos- methyl; coumaphos; diazinon; } \\
\text { dimethoate; disulfoton; ethoprophos; fenchlorphos; iprobenphos; monocrotophos; malathion; } \\
\text { malaoxon; mevinphos; omethoate; methyl paraoxon; parathion-ethyl; parathion-methyl; } \\
\text { prothiofos; phorate; phoratesulfone; phoratesulfoxide; phosphamidon and triadimefon }\end{array}$ \\
\hline Pyre & $\begin{array}{l}\text { Cypermethrin; deltamethrin; fenpropathrin; permethrin; cyfluthrin; cyhalothrin- } \lambda \text {; fenvalerate; } \\
\text { esfenvalerate and fluvalinate }\end{array}$ \\
\hline
\end{tabular}


The developed TLC plates were examined under ultraviolet light at $254 \mathrm{~nm}$ and $366 \mathrm{~nm}$. Then the plates were treated with anisaldehyde-sulphuric acid reagent followed by heating at $110^{\circ}$ till the coloured spots were developed, which were visualised in daylight. The colour and $R_{f}$ values of the resolved spots were noted.

\section{High performance thin layer chromatography (HPTLC) analysis:}

Silica Gel $60 \mathrm{~F}_{254}$ pre-coated aluminium plates (Merck $\mathrm{KGaA}$ ) of $10 \times 10 \mathrm{~cm}$ with $0.2 \mathrm{~mm}$ thickness were prewashed by methanol and activated at $60^{\circ}$ for $5 \mathrm{~min}$ prior to chromatography. Methanol extracts were diluted in methanol up to a concentration of $1 \mathrm{mg} / \mathrm{ml}$ and passed through 0.45 Millipore filters. Two microliters of each ingredient sample of $8 \mathrm{~mm}$ width was applied by auto sampler system-Camag Linomat 5. However Amrtadi churna sample was applied at an amount of $2 \mu$. HPTLC plates were developed in Camag glass twin-through chamber $(20 \times 10 \mathrm{~cm})$ previously saturated with the solvent for $60 \mathrm{~min}$ maintained at $60^{\circ}$ and $40 \%$ relative humidity (RH). The development distance was kept to be $9 \mathrm{~cm}$. Mobile phase used was toluene, chloroform, acetone, ethyl acetate, formic acid (4:3:2:1:0.5 v/v). Visualization was done at wavelengths of $254 \mathrm{~nm}$, $366 \mathrm{~nm}$ and $540 \mathrm{~nm}$, before and after spraying with anisaldehyde-sulphuric acid reagent.

\section{Thermo gravimetric analysis:}

The thermogravimetric analysis (TGA) is used to determine the total weight change in the churna formulations during thermal treatments. An accurately weighed quantity of the sample was heated in alumina crucibles with a heating rate of $10^{\circ} / \mathrm{min}$ from room temperature to $1200^{\circ}$ in a nitrogen atmosphere using a thermo gravimetric analyser TGA/STDTA $851^{\mathrm{e}}$
(Mettler, Switzerland). The biochar yield was calculated by mass balance. The data were interpreted using STARe SW 12.10 software (Mettler) ${ }^{[16,1]}$.

\section{Statistical analysis:}

Results of physicochemical and flowability parameters and of Amrtadi churna were expressed as mean \pm standard deviation (SD) of three in-house batches of the formulation.

\section{RESULTS AND DISCUSSION}

The tested foreign matter content of all the ingredients of Amrtadi churna was less than $0.5 \%(\mathrm{w} / \mathrm{w})$, which is well below the maximum permissible limits as per API. In organoleptic evaluation, the prepared in-house Amrtadi churna was found to be yellowish brown in colour with characteristic odour and tasted astringent and sore. The fluorescence behaviour of the powdered churna samples as such, as well as after treatment with different reagent solutions towards ordinary light and ultraviolet light (both long $365 \mathrm{~nm}$ and short $254 \mathrm{~nm}$ wave lengths) were observed and exhibited characteristic colours as reported in Table 3.

In the powder microscopic analysis of Amrtadi churna (fig. 1), the diagnostic characters such as the presence of pollen grains, tracheids with spiral thickenings, simple fibre and oil glands indicated the presence of lignified trichomes, rosette and prismatic crystals, lignified fibres and epicarp indicated the presence of Gokshur (T. terrestris). Stone cells, mesocarp parenchymatous cell, vascular fibres and trichomes indicated the presence of Amalaki (E. officinalis). Cork cell, stone cell, trichomes and scalariform xylem vessels were suggestive of Guduchi (T. cordifolia).

Physicochemical analysis of Amrtadi churna

\section{TABLE 3: FLUORESCENCE ANALYSIS OF AMRTADI CHURNA}

\begin{tabular}{|c|c|c|c|}
\hline \multirow[t]{2}{*}{ Powdered drug } & \multirow[t]{2}{*}{ Visible/day light } & \multicolumn{2}{|c|}{ Ultraviolet light } \\
\hline & & $254 \mathrm{~nm}$ & $366 \mathrm{~nm}$ \\
\hline Powder as such & Crimson to dark brown & No colour & No colour \\
\hline Powder+conc. $\mathrm{HCl}$ & Brown & Fluorescent green & No colour \\
\hline Powder+10\% $\mathrm{K}_{2} \mathrm{Cr}_{2} \mathrm{O}_{7}$ & Orange brown & Fluorescent green & Black \\
\hline Powder+1 M NaOH & Red brown & Fluorescent green & No fluorescent \\
\hline Powder+AgNO & Pale yellow & Fluorescent green & No fluorescent \\
\hline Powder+conc. $\mathrm{HNO}_{3}$ & Orange yellow & Fluorescent green & Black \\
\hline Powder+conc. $\mathrm{H}_{2} \mathrm{SO}_{4}$ & Reddish brown & Black & Black \\
\hline Powder $+\mathrm{Br}_{2}$ water & Pale yellow & No Fluorescent & No fluorescent \\
\hline Powder+methanol & Light brown & Fluorescent green & Fluorescent green \\
\hline Powder $+\mathrm{CH}_{3} \mathrm{COOH}$ & Yellow & Fluorescent green & Brown \\
\hline Powder $+\mathrm{NH}_{3}$ & Pale orange & Fluorescent green & Brown \\
\hline Powder $+\mathrm{I}_{2}$ & Greyish brown & No colour & No colour \\
\hline
\end{tabular}




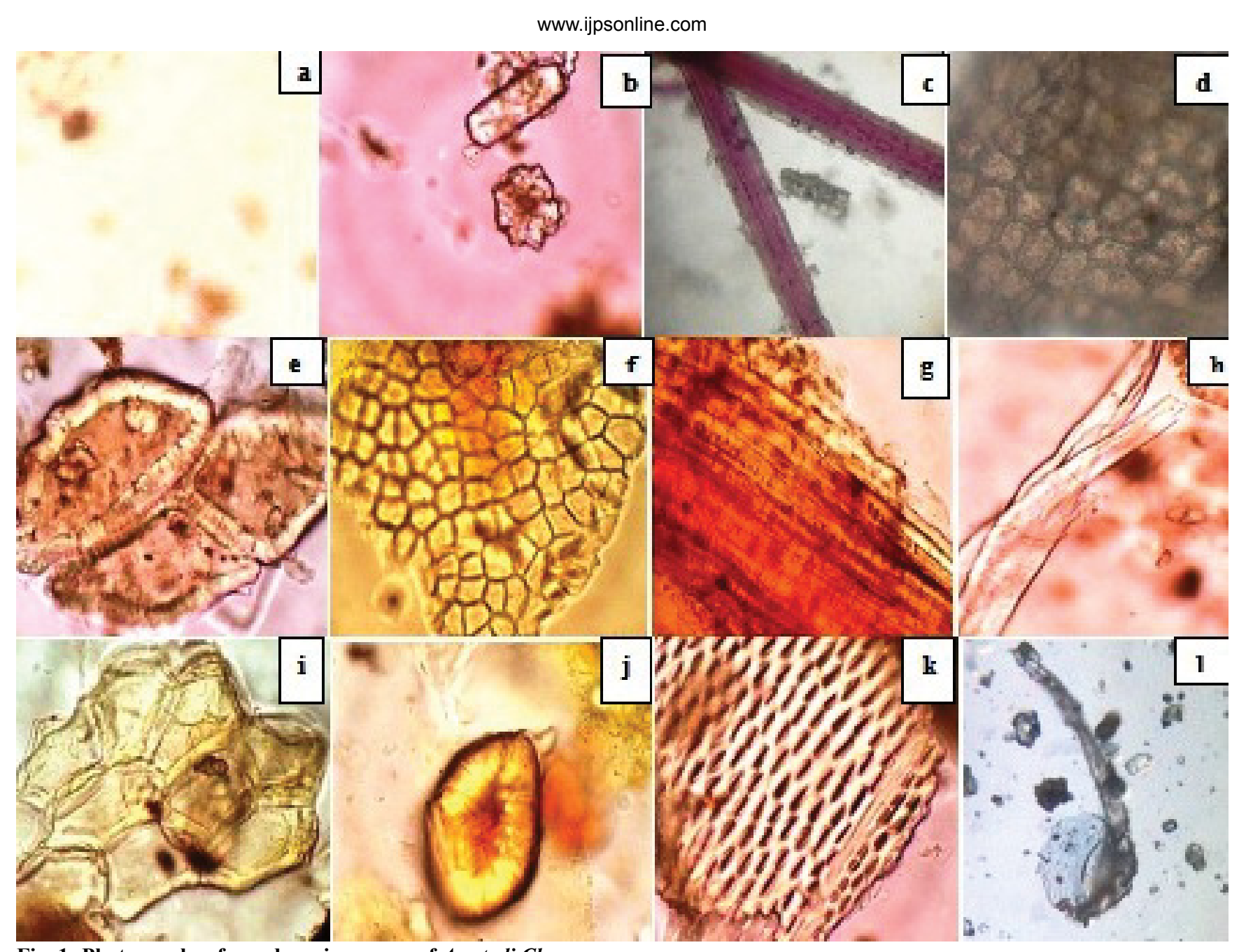

Fig. 1: Photographs of powder microscopy of Amrtadi Churna

(a) Lignified trichomes of Gokshur, (b) rosette and prismatic crystals of Gokshur, (c) lignified fibres of Gokshur, (d) epicarp of Gokshur, (e) stone cells of Amalaki, (f) mesocarp parenchymatous cell of Amalaki, (g) vascular fibres of Amalaki, (h) trichomes of Amalaki, (i) cork cell of Guduchi, (j) stone cell of Guduchi, (k) scalariform xylem vessels of Guduchi, (l) trichomes of Guduchi

(mean \pm SD of three batches) showed $13.203 \pm 0.041 \%$ $\mathrm{w} / \mathrm{w}$ water soluble extractive, $2.669 \pm 0.054 \% \mathrm{w} / \mathrm{w}$ ethanol soluble extractive, $10.165 \pm 0.03 \mathrm{w} / \mathrm{w}$ total ash, $1.778 \pm 0.062 \% \mathrm{w} / \mathrm{w}$ acid insoluble ash, $13.706 \pm 0.012 \%$ $\mathrm{w} / \mathrm{w}$ loss on drying at $105^{\circ}$ and $\mathrm{pH}$ of $5.229 \pm 0.015$ for its $1 \%$ aqueous suspension. The flowability of Amrtadi churna was determined by various parameters (bulk density, tap density, angle of repose, Hausner's ratio and Carr's index), which were given in Table 4.

The comparative phytochemical evaluation of Amrtadi churna and its individual ingredients in solvents of different polarity were carried out and presented in Table 5. The preliminary phytochemical screening of different extracts revealed the presence of phytoconstituents like alkaloids, tannins, steroids, flavonoids, saponins, carbohydrates and proteins.

The microbial profile revealed that the total microbial count, yeast and mould count (total fungal count)
TABLE 4: EVALUATION OF FLOW PROPERTIES OF AMRTADI CHURNA

\begin{tabular}{cc}
\hline Parameters & Value $^{*}$ \\
\hline Tap density & $0.367 \pm 0.024$ \\
Bulk density & $0.326 \pm 0.004$ \\
Angle of repose & $38.689 \pm 0.520$ \\
Hausner's ratio & $1.306 \pm 0.129$ \\
Carr's index & $0.128 \pm 0.042$ \\
\hline
\end{tabular}

*Values expressed as mean $\pm \mathrm{SD}(\mathrm{n}=9)$ with 3 observations from each batch

of our in-house Amrtadi churna were found to be below API specified limits (Table 6) ${ }^{[9]}$. Moreover, the pathogenic bacteria, Salmonella, Pseudomonas, Staphylococcus and E. coli were also found to be absent (Table 6). In heavy metals evaluation (Table 7), different tested metals, namely $\mathrm{Cd}, \mathrm{As}, \mathrm{Hg}, \mathrm{Pb}, \mathrm{Cu}, \mathrm{Zn}$, $\mathrm{Ni}$ and $\mathrm{Cr}$ in Amrtadi churna were detected within the limits specified, whenever available ${ }^{[15]}$. Again, tested aflatoxins (B1, B2, G1 and G2) were found to be below the limit of detection (MDL) of API ${ }^{[9]}$. Moreover, none 
TABLE 5: PHYTOCHEMICAL INVESTIGATION OF RAW MATERIALS AND AMRTADI CHURNA

\begin{tabular}{lcc}
\hline Material & Extracts & Phytoconstituents present \\
\hline Gokshur & Aqueous extract & A, G, F, Sa, P,T \\
& Methanol extract & A, G, F, Sa, T \\
& Ethyl acetate extract & F, Sa, C \\
Chloroform extract & Sa, C \\
Amalaki & Pet. ether extract & - \\
& Aqueous extract & A, T, Sa, C \\
& Methanol extract & T, G, F, Sa, C \\
& Ethyl acetate extract & Sa, C, P \\
Chloroform extract & T, St, G, F, C \\
& Pet. ether extract & St \\
& Aqueous extract & T, G, Sa, C, P, F \\
& Methanol extract & T, G, Sa, C, F \\
& Ethyl acetate extract & G, Sa, C, St \\
Chloroform extract & F, Sa, C \\
& Pet. ether extract & St \\
& Aqueous extract & T, G, F, Sa, C, P \\
& Methanol extract & T, G, F, Sa, P \\
& Ethyl acetate extract & G, F, C, P \\
& Chloroform extract & St, G, F, Sa, C, P \\
& Pet. ether extract & St \\
\hline
\end{tabular}

A: alkaloids, T: tannins, St: steroid, G: glycoside, F: flavonoids, Sa: saponins, C: carbohydrates, P: proteins and Te: terpenoids

TABLE 6: RESULTS OF MICROBIAL LOAD OF AMRTADI CHURNA

\begin{tabular}{lcc}
\hline Microbial analysis & Limit $^{*}$ & Observation \\
\hline Total bacterial count & $\mathrm{NMT} 10^{5} \mathrm{CFU} / \mathrm{ml}$ & $270 \mathrm{CFU} / \mathrm{ml}$ \\
Total yeast and mould & $\mathrm{NMT} 10^{3} \mathrm{CFU} / \mathrm{ml}$ & $2 \mathrm{CFU} / \mathrm{ml}$ \\
E. coli & Absent & Absent \\
S. spp. & Absent & Absent \\
S. aureus & Absent & Absent \\
P. areuginosa & Absent & Absent \\
\hline
\end{tabular}

${ }^{*}$ As per limits mentioned Ayurvedic Pharmacopoeia of India (API)

TABLE 7: HEAVY METAL ANALYSIS OF AMRTADI CHURNA

\begin{tabular}{ccc}
\hline Heavy Metal & Standard limit (ppm) & Observed value (ppm) \\
\hline Arsenic & $3 \mathrm{ppm}$ & $1.08 \mathrm{ppm}$ \\
Lead & $10 \mathrm{ppm}$ & $1.31 \mathrm{ppm}$ \\
Mercury & $1 \mathrm{ppm}$ & $0.40 \mathrm{ppm}$ \\
Cadmium & $0.3 \mathrm{ppm}$ & $0.02 \mathrm{ppm}$ \\
Nickel & $\mathrm{NA}$ & $2.71 \mathrm{ppm}$ \\
Zinc & $\mathrm{NA}$ & $16.34 \mathrm{ppm}$ \\
Copper & $\mathrm{NA}$ & $6.67 \mathrm{ppm}$ \\
Chromium & $\mathrm{NA}$ & $4.88 \mathrm{ppm}$ \\
\hline
\end{tabular}

*As per limits mentioned in Ayurvedic Pharmacopoeia of India (API). NA- not available in API

of the tested pesticides (i.e., organochlorine pesticides, organophosphorus pesticides and pyrethroids) were detected with a detection limit of $0.01 \mathrm{mg} / \mathrm{kg}^{[15]}$.

FTIR spectrophotometric profiling for methanol extract of all three batches of Amrtadi churna displayed generally similar profile (fig. 2). The functional groups of the components were separated in FTIR spectrum based on their peak ratios. The assignments of functional groups for all the batches are summarized in
Table 8. The FTIR profile of the first and the third batch of Amrtadi churna showed 15 prominent peaks, while the second batch produced 14 peaks.

The comparative TLC profile of the methanol extracts of Amrtadi churna with that of its ingredients showed good separation of components with unique spots $\left(\mathrm{R}_{\mathrm{f}}\right.$ values), indicating presence of Gokshur, Amalaki and Guduchi. The results of TLC study are shown for the solvent system:toluene:chloroform:acetone:ethyl 


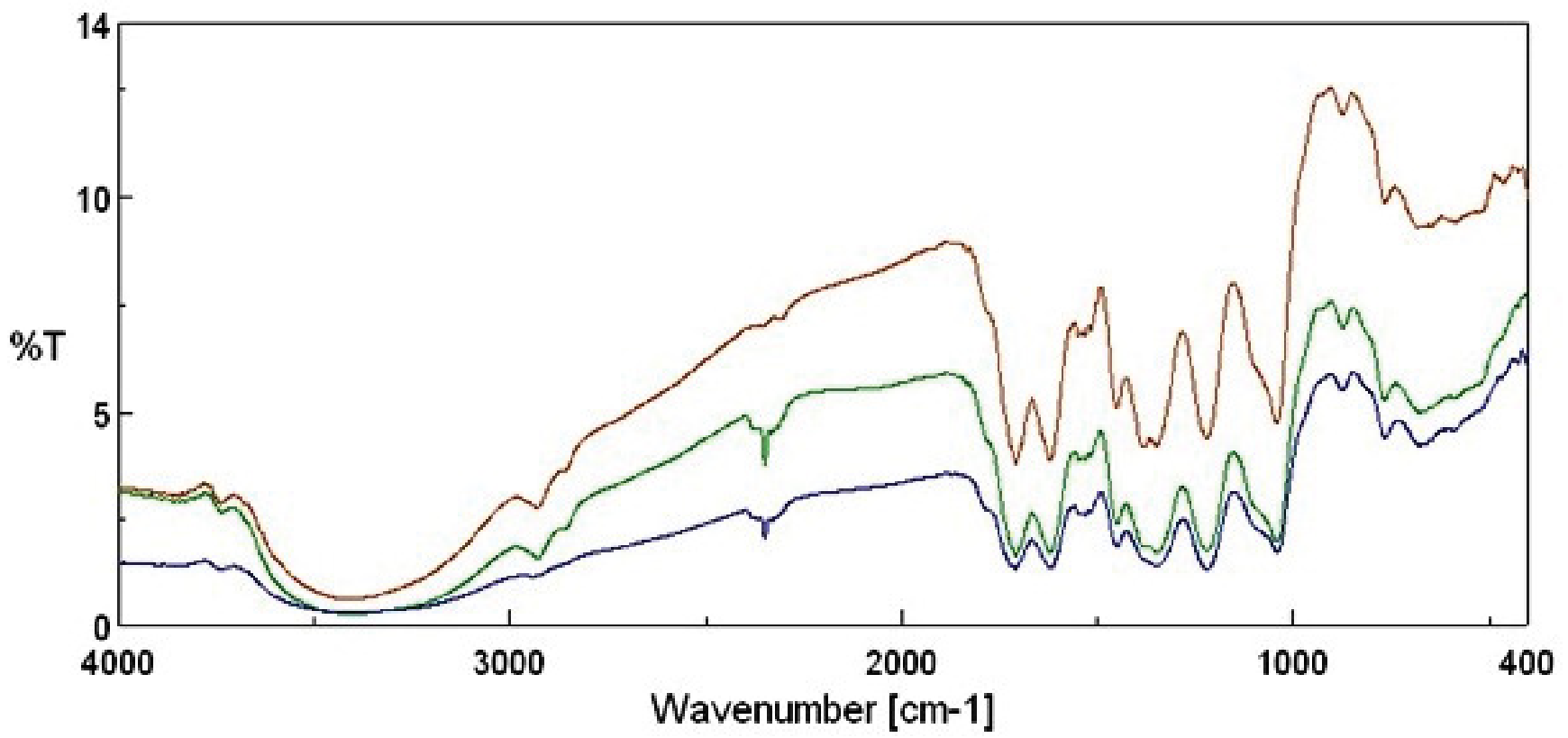

Fig. 2: FTIR spectra of different batches of Amrtadi churna

TABLE 8: COMPARATIVE FTIR PEAK VALUES AND FUNCTIONAL GROUPS OF THREE BATCHES OF AMRTADI CHURNA

\begin{tabular}{|c|c|c|c|c|}
\hline \multicolumn{3}{|c|}{ Peak value $\left(\mathrm{cm}^{-1}\right)$} & \multirow[t]{2}{*}{ Bond type } & \multirow[t]{2}{*}{ Functional group } \\
\hline Batch 1 & Batch 2 & Batch 3 & & \\
\hline 3851.15 & 3853.08 & 3854.04 & Unknown & Unknown \\
\hline 3735.44 & 3734.48 & 3736.41 & Unknown & Unknown \\
\hline 3390.25 & 3414.35 & 3401.82 & $\mathrm{~N}-\mathrm{H}$ stretching & Amide \\
\hline 2931.27 & 2350.8 & 2933.2 & Alkyl C-H stretch & Alkane \\
\hline 2355.62 & Absent & 2356.59 & Unknown & Unknown \\
\hline 1708.62 & 1712.48 & 1708.62 & $\mathrm{C}=\mathrm{O}$ stretching & Aldehyde/ketone \\
\hline 1621.84 & 1622.81 & 1621.84 & $\mathrm{C}=\mathrm{C}$ bending & Aromatic \\
\hline 1539.88 & 1536.99 & 1540.85 & $\mathrm{~N}-\mathrm{O}$ asymmetric stretch & Nitro compound \\
\hline 1449.24 & 1445.39 & 1450.21 & C-H Bending & Alkanes \\
\hline 1348 & 1351.86 & 1381.75 & $\mathrm{C}-\mathrm{H}$ rock & Alkanes \\
\hline 1220.72 & 1220.72 & 1221.68 & C-N stretch & aliphatic amines \\
\hline 1044.27 & 1047.16 & 1043.3 & C-O stretch & Alcohols/carboxylic acids/esters/ethers \\
\hline 872.63 & 875.52 & 873.6 & $=\mathrm{C}-\mathrm{H}$ bend & Alkenes \\
\hline 764.64 & 760.78 & 762.71 & $\mathrm{C}-\mathrm{H}$ bending & Aromatics \\
\hline 672.07 & 670.14 & 670.14 & Alkene $\mathrm{C}-\mathrm{H}$ bending & Alkynes \\
\hline
\end{tabular}

acetate:formic acid (4:3:2:1:0.5) in Table 9 (254 $\mathrm{nm})$ and Table 10 (366 nm). The HPTLC chromatograms of the methanol extracts of Amrtadi churna also conformed unique spots for each and every ingredient on the basis of comparative $\mathrm{R}_{\mathrm{f}}$ values. Plate images as well as $3 \mathrm{D}$ chromatograms at scanned wavelengths (i.e. 254, 366 and $540 \mathrm{~nm}$ ) before and after derivatization with anisaldehyde sulphuric acid reagent have been presented in figs. 3-5.

The pyrolytic character of Amrtadi churna obtained from its TG curve showed a plot of temperature vs. weight of the sample and is displayed as $\mathrm{Z}$ shaped curve from left to right categorized into three stages (fig. 6). The first decomposition stage was present up to approximately $161^{\circ}$ contributing mass loss of $5.31 \%$ $\mathrm{w} / \mathrm{w}$. The second degradation stage $\left(161-423^{\circ}\right)$ results $49.02 \% \mathrm{w} / \mathrm{w}$ mass losses, while the third degradation stage $\left(423-1198^{\circ}\right)$ contributed $28.59 \% \mathrm{w} / \mathrm{w}$ mass loss. The total mass loss during these three stages was about $82.93 \%$.

Herbal drugs should be free from foreign matters like other parts of the same plant, other plant parts, moulds or insects including their excreta, visible contaminant such as sand and stones, poisonous and harmful chemical residues. It is essential that the amount of foreign matter in herbal products is within than the 
TABLE 9: TLC SCREENING OF RAW MATERIALS VS. DIFFERENT BATCHES OF AMRTADI CHURNA AT $254 \mathrm{~nm}$

\begin{tabular}{cccccc}
\hline \multicolumn{1}{l}{$\mathrm{R}_{\mathrm{f}}$ Values } \\
\hline Track A (Gokshur) & Track B (Amalaki) & Track C (Guduchi) & Track S (Batch 1) & Track S \\
\hline 0.05 & 0.01 & 0.02 & 0.01 & 0.01 & 0.01 \\
- & 0.07 & 0.08 & 0.02 & 0.02 & 0.02 \\
- & 0.11 & - & 0.05 & 0.05 & 0.05 \\
- & - & - & 0.07 & 0.07 & 0.07 \\
- & - & - & 0.08 & 0.08 & 0.08 \\
- & - & - & 0.11 & 0.11 & 0.11 \\
\hline
\end{tabular}

TABLE 10: TLC SCREENING OF RAW MATERIALS VS. DIFFERENT BATCHES OF AMRTADI CHURNA AT $366 \mathrm{~nm}$

\begin{tabular}{|c|c|c|c|c|c|}
\hline \multicolumn{6}{|l|}{$\overline{R_{f} \text { Values }}$} \\
\hline Track A (Gokshur) & Track B (Amalaki) & Track C (Guduchi) & Track $\mathrm{S}_{1}$ (Batch 1) & Track $\mathrm{S}_{2}$ (Batch 2) & Track $\mathrm{S}_{3}$ (Batch 3) \\
\hline 0.12 & 0.09 & 0.01 & 0.01 & 0.01 & 0.01 \\
\hline 0.76 & 0.25 & 0.04 & 0.04 & 0.04 & 0.03 \\
\hline 0.81 & 0.78 & 0.36 & 0.09 & 0.09 & 0.09 \\
\hline - & - & 0.40 & 0.12 & 0.12 & 0.13 \\
\hline - & - & 0.47 & 0.20 & 0.21 & 0.21 \\
\hline - & - & 0.59 & 0.25 & 0.25 & 0.25 \\
\hline - & - & 0.72 & 0.36 & 0.36 & 0.36 \\
\hline - & - & - & 0.40 & 0.40 & 0.40 \\
\hline - & - & 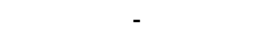 & 0.59 & 0.59 & 0.59 \\
\hline- & - & . & 0.72 & 0.72 & 0.72 \\
\hline - & - & - & 0.78 & 0.78 & 0.78 \\
\hline- & - & - & 0.81 & 0.81 & - \\
\hline
\end{tabular}

standard prescribed according to the pharmacopoeia monograph. On the other hand, organoleptic properties are the aspects of food or other substances as experienced by the senses, including taste, sight, smell, and touch. Deviation in these properties gives a primary indication about quality variation. Moreover, many plant constituents show fluorescence in the visible/ ultraviolet light or they may often be converted into fluorescent derivatives by applying different reagents. Fluorescence analysis is an important parameter of pharmacognostic evaluation and many crude drugs are assessed qualitatively by this technique. Hence we analysed Amrtadi churna for its percentage of foreign matter, organoleptic properties as well as fluorescence characteristics for rapid assessment of its quality.

Powder microscopy is used to study the specific microscopic characters of medicinal plants using different staining reagent. These studies provide a suitable diagnostic tool for the standardization as well as identification of adulterants. This method is also very useful in conforming presence of ingredients of a polyherbal powder. In the powder microscopic analysis, the microscopic features present in Amrtadi churna confirmed the presence of its every herbal ingredient (fig. 1).

Established physicochemical standards give important information for further investigations and facilitate the quality evaluation of herbal formulations in routine industrial production. In this respect, the test for loss on drying determines both water and volatile matter. Total ash measures the amount of materials remaining after ignition. Acid insoluble ash measures the amount of silica present, especially sand and siliceous matter. Extracting values (alcohol and water soluble extractive) measure consistency and amount of chemical constituents present in herbal drugs. Considering the importance of these physicochemical parameters, Amrtadi churna was characterised by evaluating water soluble extractive, ethanol soluble extractive, total ash content, acid insoluble ash, $\mathrm{pH}$ and loss on drying at $105^{\circ}$.

Understanding of powder flow is crucial during mixing, packaging and transportation of the pharmaceutical manufacturing process. There are various parameters evaluated to measure the powder flow such as the angle of repose, the bulk density, the tapped density, the 

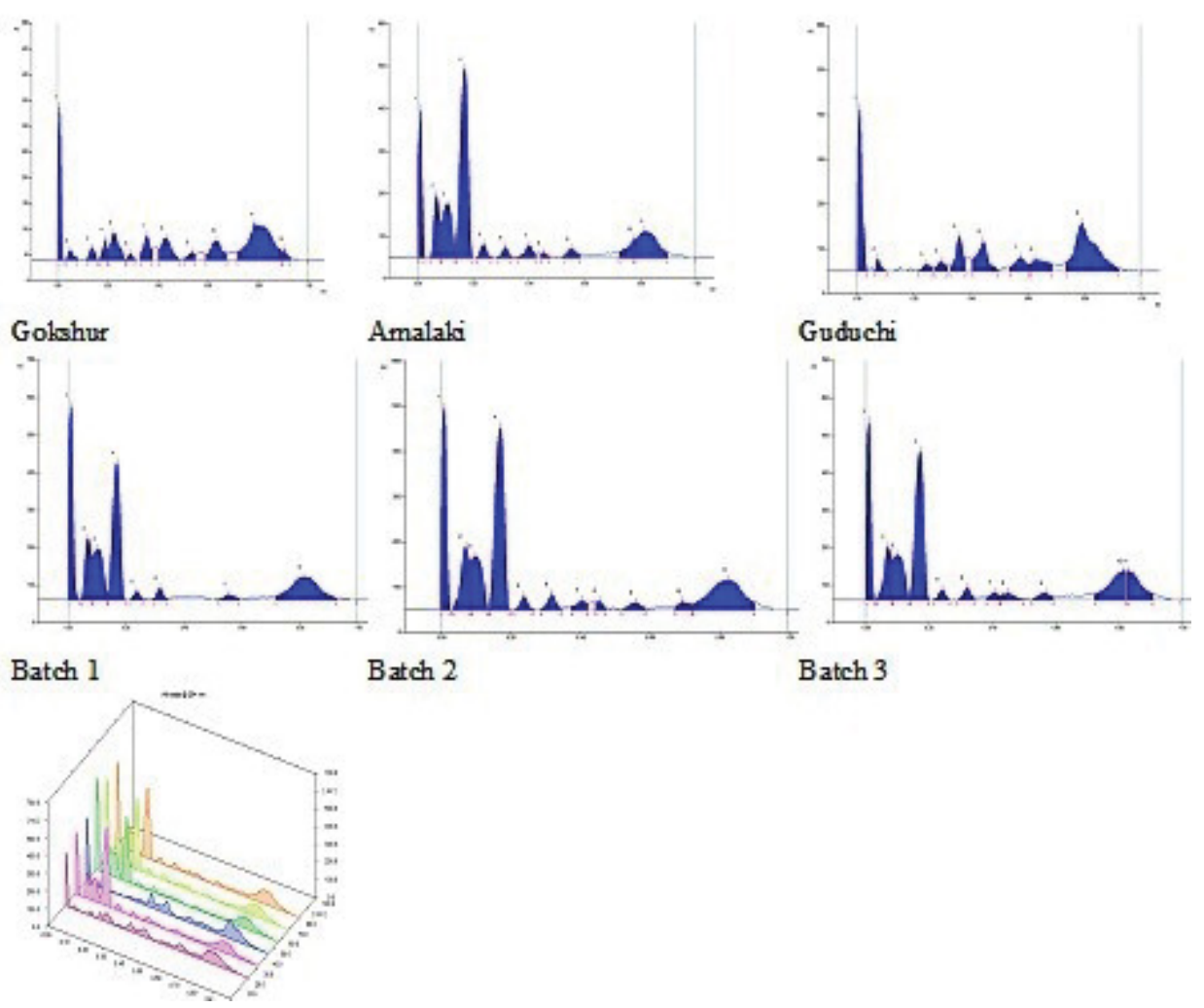

Batch 2

Batch 3

a


Batch 1

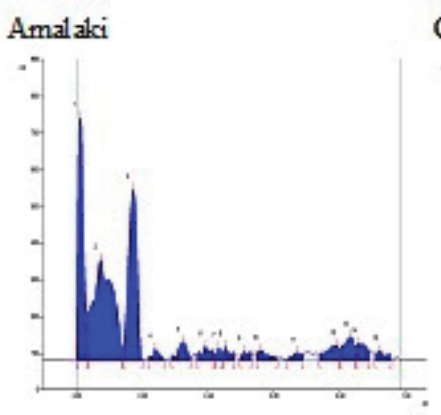

Guduchi

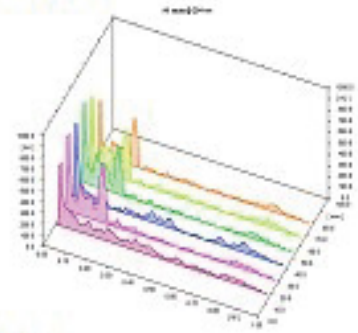

Batch 2

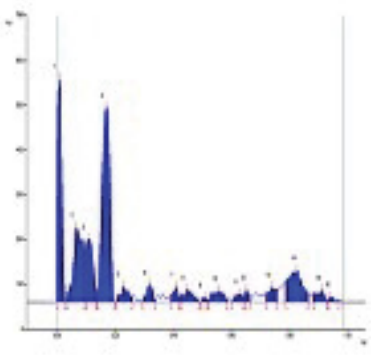

Batch 3

b

Fig. 3: HPTLC of raw materials and different batches of Amrtadi Churna at $254 \mathbf{n m}$ before and after derivatization a. HPTLC screening of raw materials vs. different batches of Amrtadi Churna at $254 \mathrm{~nm}$ before derivatization; b. HPTLC screening of raw materials vs. different batches of Amrtadi Churna at $254 \mathrm{~nm}$ after derivatization 


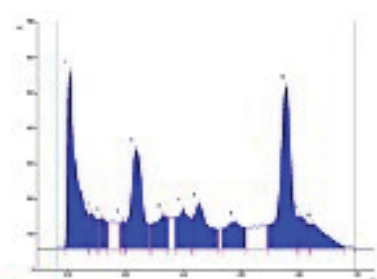

Goloshur

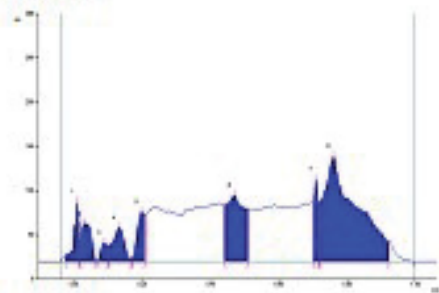

Batch 1

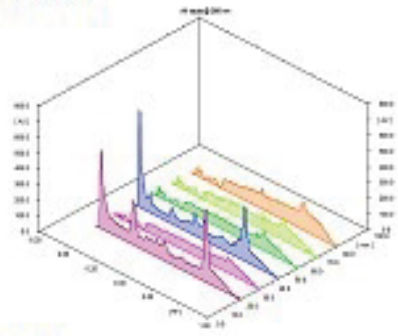

3D

a

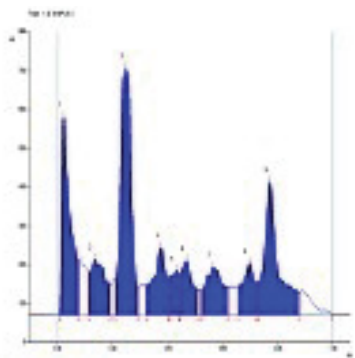

\section{Golshur}

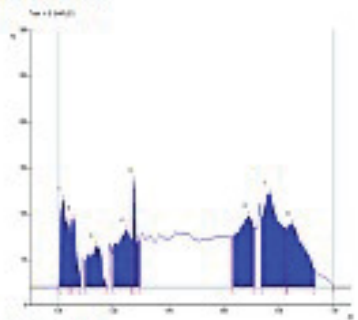

Batch 1

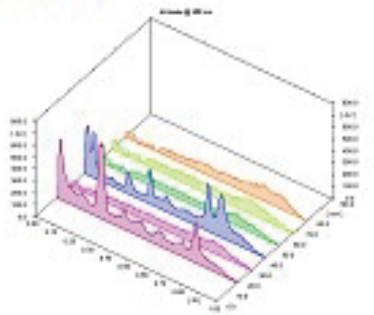

\section{$=$}

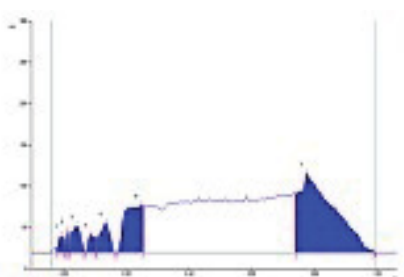

Amalaki

$+$

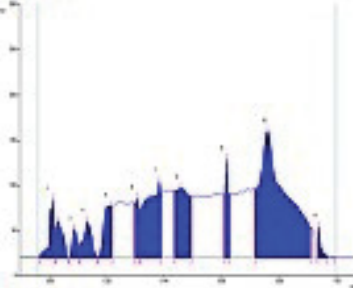

Batch 2

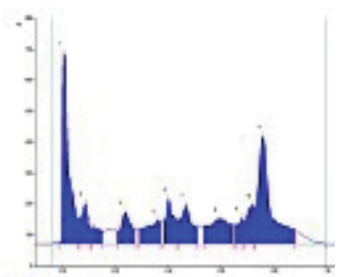

Guduchi

"7

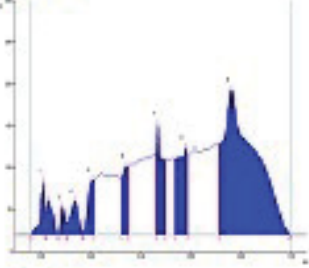

Batch 3
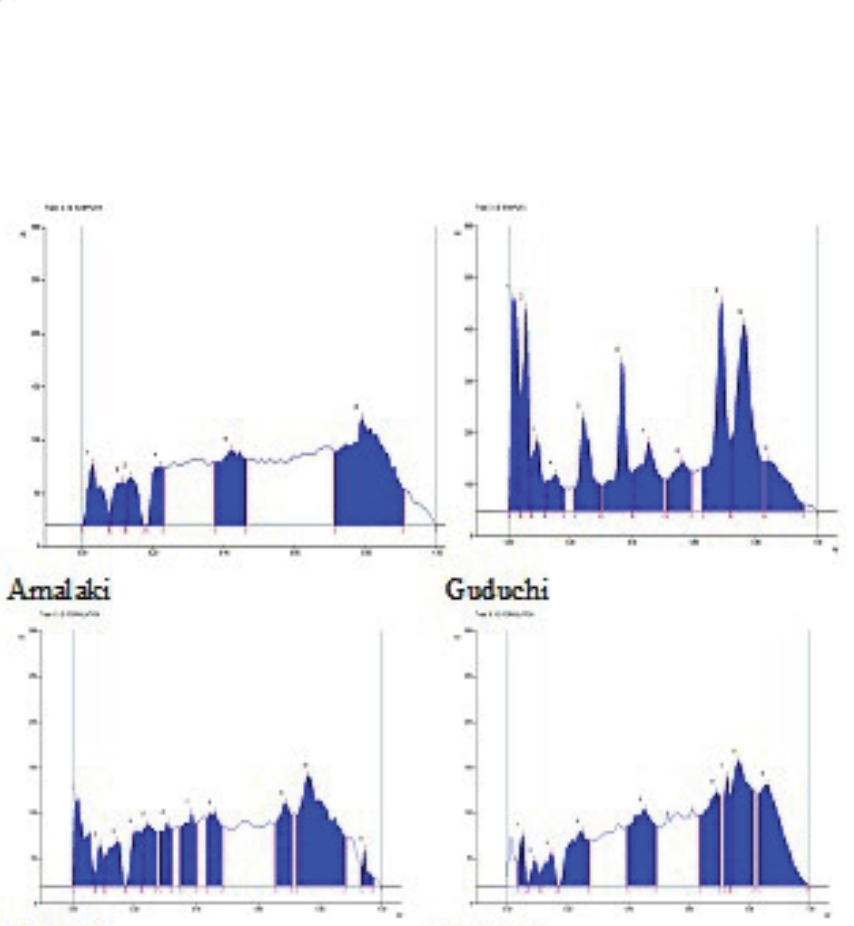

Batch 2

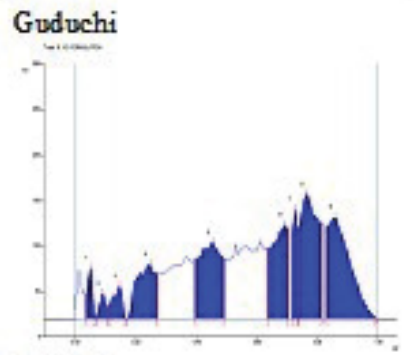

Batch 3

b

Fig. 4: HPTLC of raw materials vs. different batches of Amrtadi Churna at $366 \mathrm{~nm}$ before and after derivatization a. HPTLC screening of raw materials vs. different batches of Amrtadi Churna at $366 \mathrm{~nm}$ before derivatization; b. HPTLC Screening of raw materials vs. different batches of Amrtadi Churna at $366 \mathrm{~nm}$ after derivatization 
www.ijpsonline.com
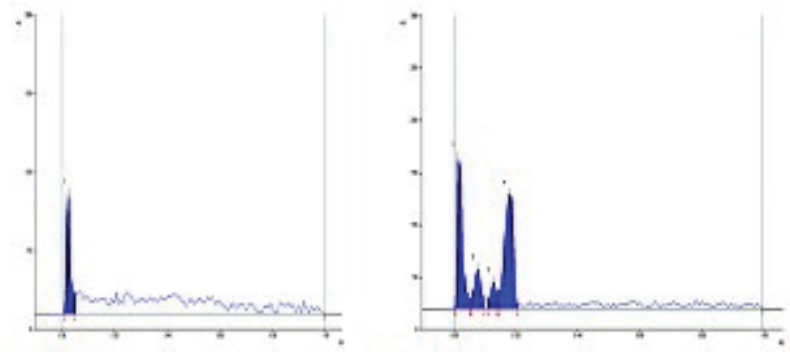

Golshur

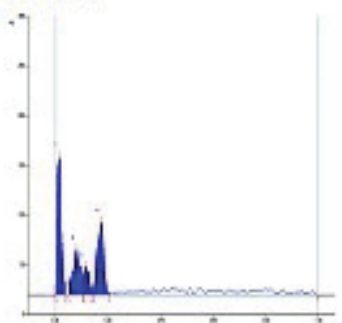

Batch 1

Amalaki

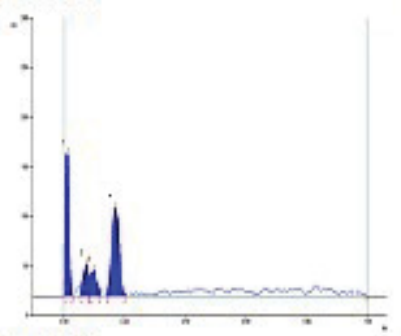

Batch 2

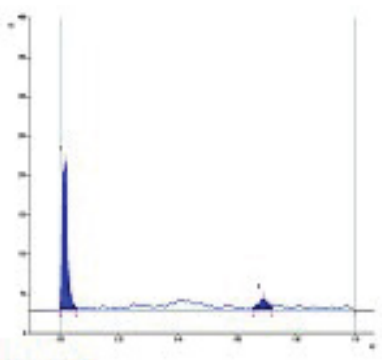

Guduchi



Batch 3

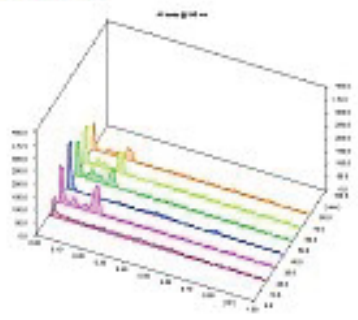

3D

Fig. 5: HPTLC screening of raw materials vs. different batches of Amrtadi Churna at $540 \mathrm{~nm}$ after derivatization

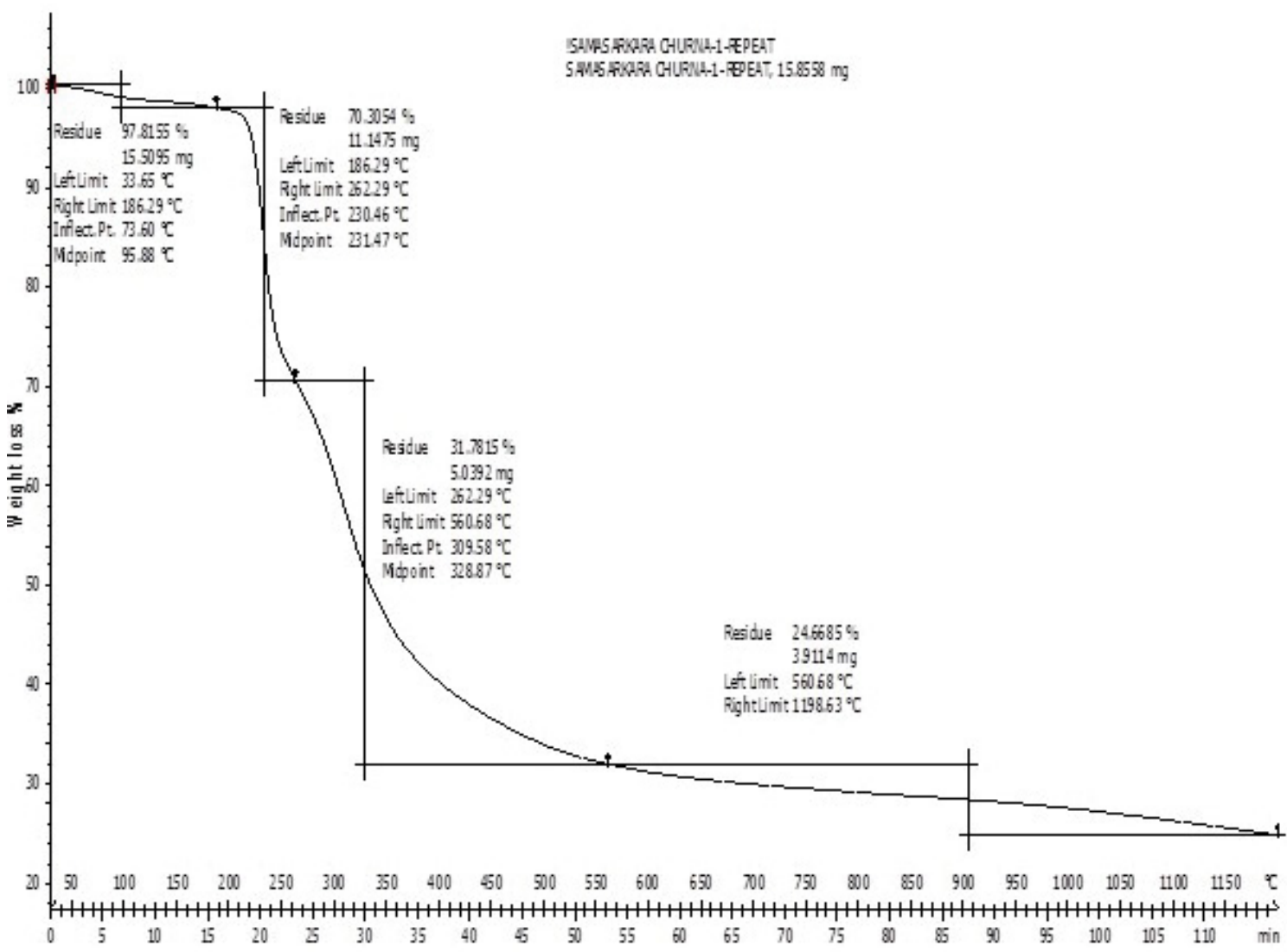

Fig. 6: Thermal gravimetric analysis of Amrtadi Churna 
Carr's compressibility index and the Hausner's ratio. Fine particles with smaller bulk/tapped density are less free-flowing, whereas, larger denser particles tend to be freer flowing. The angle of repose is another quick test for monitoring the powder's flow and obtaining relative measures of flowability. Angles of repose under $30^{\circ}$ point to powders with good flowability, $30-45^{\circ}$ show some cohesiveness, $45-55^{\circ}$ show true cohesiveness and anything above $55^{\circ}$ is considered to have very high cohesiveness and limited flowability ${ }^{[28]}$. A Hausner's ratio of less than 1.25 indicates a powder that is free flowing whereas values above 1.25 indicate poor flow ability. Finally, the smaller the Carr's Index has the better the flow properties. In the evaluation of powder flow characteristics of Amrtadi churna, the flow ability was found to be poor with low tap density and bulk density values. This was further confirmed by high values of angle of repose, Hausner's ratio and Carr's index in Table 4.

Phytochemicals are chemical compounds that occur naturally in plants. Factors such as geographical location, harvest time, plant part used and method of isolation affect the chemical composition of the herbal ingredients. Proper phytochemical composition is highly essential for the satisfactory efficacy of herbal products. In this relation, the comparative phytochemical evaluation of Amrtadi churna and its individual ingredients in solvents of different polarity are carried out. Phytoconstituents like phenolic, flavonoids, tannins etc., have been previously found to be useful in the management of antiulcer ${ }^{[18]}$. The presence of the said constituents in Amrtadi churna may be responsible for its clinical usefulness as antiulcer agent.

The presence of microbial contaminants in herbal products can reduce or even inactivate the therapeutic activity of the products and has the potential to adversely affect patients taking these medicines. Thus, manufacturers should ensure the lowest possible level of microorganisms in the raw material, finished dosage forms and the packaging components to maintain appropriate quality, safety and efficacy of the natural products.

The contaminations of heavy toxic metals in plants could develop serious health problems because there is a narrow concentration range between the deficiency and toxicity levels of the heavy metals in human ${ }^{[29]}$. WHO has emphasized on various standard analytical techniques for the analysis of toxic heavy metals in plant products to ascertain their safety ${ }^{[30]}$.
Aflatoxins, the secondary metabolites produced by the Aspergillus species (namely Aspergillus flavus, A. parasiticus) contaminate a variety of agricultural and food commodities. Aflatoxins are classified into a number of subtypes. However, the most important ones are B1, B2, G1 and G2. These mycotoxins are recognized to be hepatotoxins and carcinogens in humans. WHO urges the levels of Aflatoxins to be reduced to as low as reasonably achievable ${ }^{[31]}$. Contamination of medicinal plants with pesticide residues also poses significant health risks that include carcinogenesis. Hence it is important to develop an effective method for the detection of these compounds. In our study with in house Panchasakara churna formulation, the microbial profile was found to be satisfactory. In addition, the limits of all the specified heavy metals in the churna were found within the API acceptable range.

FTIR spectroscopy is proved to be a reliable and sensitive method for detection of biomolecular composition ${ }^{[32]}$. The FTIR spectrum is used to identify the functional groups of the components of plant extracts based on the peak values in the region of IR radiation. FTIR spectrophotometric profiling for methanol extract of all three batches of Amrtadi churna displayed generally similar profile (fig. 2). This similarity of assigned peak position on the FTIR spectrum of all three batches of Amrtadi churna justified the similarity in their phytochemical composition. The FTIR profile similarity between batches of Amrtadi churna could therefore be used to determine the identity and to control the quality of the formulation.

TLC and HPTLC have excellent resolution and permit simultaneous identification of a wide range of substances in a single run. Hence, they can be utilised as important tools for the quality control and fingerprint of herbal products. They also help to identify the presence or absence of the individual herbs in combination herbal formulations ${ }^{[33]}$. The main objective of our TLC/ HPTLC study of Amrtadi churna was to develop unique spots $\left(\mathrm{R}_{\mathrm{f}}\right.$ values) in the formulation as an identifier of its every ingredient.

TGA is rapid, reliable and reproducible technique for material characterization by application of heat. In this technique, the loss in weight over a specific temperature provides valuable information about the composition of the sample and its thermal stability. TG characterizations of plant materials provide information about the contents of volatile and heat labile compounds 
present in them, giving major support to the analysis of plant materials during standardization.

The pyrolytic character of Amrtadi churna obtained from its TG curve (fig. 6) occurred in three stages. The first decomposition stage present approximately up to $161^{\circ}$ might be attributed to loss of water content and volatile oils mainly the monoterpenes. The second decomposition stage of $161-423^{\circ}$ indicated decomposition of plant materials as well as the evolution of turbostratic crystallites during pyrolysis ${ }^{[26]}$. In the final (third) degradation stage of $423-\mathrm{k} 1198^{\circ}$, there was weight stabilization of the biochar due to decomposition of more heat-resistant components like lignins.

Inthepresentwork, the Amrtadichurnawascharacterized on the basis of the pharmacognostic, physicochemical, pharmaceutical, microbiological, toxicological, FTIR spectrophotometric and chromatographic parameters. The analytical specifications were established for the product with respect to authentic raw materials. The chromatographic data showed presence all ingredients in the formulation Amrtadi churna with their unique $\mathrm{R}_{\mathrm{f}}$ values. The parameters presented in this paper may be used for the preparation of the monograph on quality standards for Amrtadi churna to maintain its batch-tobatch consistency. This document could also be utilised for FTIR spectroscopy and HPTLC chromatography based rapid authentication of the formulation.

\section{Acknowledgements:}

The authors wish to thank botanist Miss. Rashmibala Sahoo, Scientific officer of the Department of Botany, State Drug Testing and Research Laboratory (ISM), Bhubaneswar, Odisha, India for authenticating the plant samples and Siksha 'O' Anusandhan University, Bhubaneswar, India for providing a Ph. D. fellowship to Ms. Sangeeta Mukhi.

\section{Conflict of interests:}

Authors declare no conflict of interests.

\section{Financial support and sponsorship:}

Nil.

\section{REFERENCES}

1. Ayurvedic Formulary of India. Part 3. 1st ed. New Delhi: Ministry of Health and Family Welfare, Department of AYUSH, Government of India; 2011. p. 169.

2. Vaidya AD, Devasagayam TP. Current status of herbal drugs in India: an overview. J Clin Biochem 2007;41:1-11.
3. Bhope SG, Nagore DH, Kuber VV, Gupta PK, Patil MJ. Design and development of a stable polyherbal formulation based on the results of compatibility studies. Pharmacognosy Res 2011;3:122-9.

4. Mukherjee PK, Houghton PJ. Evaluation of Herbal Medicinal Products - Perspectives of Quality, Safety and Efficacy. UK: Pharmaceutical Press, Royal Pharmaceutical Society of Great Britain; 2009. p. 3-12.

5. Sahoo N, Manchikanti P, Dey S. Herbal drugs: standards and regulation. Fitoterapia 2010;81:462-71.

6. Park HS, Kim SR, Kim JO, Lee YC. The roles of Phytochemicals in bronchial asthma. Molecules 2010;15:6810-34.

7. Liu W, Wang Y, He DD, Li SP, Zhu YD, Jiang B. Antitussive, expectorant, and bronchodilating effects of quinazoline alkaloids $( \pm)$-vasicine, deoxyvasicine, and $( \pm)$-vasicinone from aerial parts of Peganum harmala L. Phytomedicine 2015;22:1088-95.

8. Kalaiselvan V, Shah AK, Patel FB, Shah CN, Kalaivani M, Rajasekaran A. Quality assessment of different marketed brands of Dasamoolaristam, an Ayurvedic formulation. Int J Ayurveda Res 2010;1:10-3.

9. Ayurvedic Pharmacopoeia of India. Part 2. 1st ed., Vol. 2. New Delhi: Ministry of Health and Family Welfare, Department of AYUSH, Government of India; 2008.

10. Zhang J, Wider B, Shang H, Li X, Ernst E. Quality of herbal medicines: challenges and solutions. Complement Ther Med 2012;20:100-6.

11. Patra KC, Kumar KJ, Suresh P. Standardization of a polyherbal Siddha formulation, Amukkara Choornam. Indian J Tradit Knowl 2009; 8:449-52.

12. Mulla SK, Swamy P. Preliminary pharmacognostical and phytochemical evaluation of Portulaca quadrifida Linn. Int J PharmTech Res 2010;2:1699-702.

13. Evans WC. Trease and Evans Pharmacognosy. 15th ed. London: Bailliere Tindall; 1983. p. 538-47.

14. Singh S, Machawal L, Chauhan MG. Pharmacognostic study of male leaves of Trichosanthes dioica Roxb. with special emphasis on microscopic technique. J Pharmacognosy Phytother 2010;2:71-5.

15. http://plimism.nic.in/Protocol For Testing.pdf.

16. Elamthuruthy AT, Shah CR, Khan TA, Tatke PA, Gabhe SY. Standardization of marketed Kumariasava-an Ayurvedic Aloe vera product. J Pharm Biomed Anal 2005;37:937-41.

17. Bharadwaj A, Upadhayaya K, Madhav NVS. Standardization and phytochemical investigation of antilithiatic polyphyto dispersible tablets. J Acute Dis 2014;145-7.

18. Patel JJ, Acharya SR, Acharya NS. Clerodendrum serratum (L.) Moon. -A review on traditional uses, phytochemistry and pharmacological activities. J Ethnopharmacol 2014;154:268-85.

19. Rout KK, Parida S, Mishra SK. Standardization of the ayurvedic formulation Haridra Khanda using high performance thin layer chromatography densitometry. J AOAC Int 2008; 91:1162-8.

20. Maranhao TA, Silva JS, Andrade RM, Bascunan VL, Oliveira FJ, Curtius AJ. Determination of As and $\mathrm{Hg}$ in acetic acid extract by vapour generation coupled to atomic spectrometry for solid waste classification. Microchem J 2013;106:139-46.

21. Rajput S, Tripathi MK, Tiwari AK, Dwivedi N, Tripathi SP. Scientific evaluation of Panchkola Churna -An Ayurvedic polyherbal drug formulation. Indian $\mathrm{J}$ Tradit Knowl 2012;11:697-703. 
22. Rai V, Kakkar P, Misra C, Ojha SK, Srivastava N, Mehrotra $\mathrm{S}$. Metals and organochlorine pesticide residues in some herbal ayurvedic formulations. Bull Environ Contam Toxicol 2007;79:269-72.

23. Baragi UC, Baragi PC, Vyas MK, Shukla VJ. Standardization and quality control parameters of Dashanga Kwatha ghana tablet: An Ayurvedic formulation. Int $\mathrm{J}$ Ayurveda Res 2011;2:42-7.

24. Stroka J, Anklam E, Jorissen U, Gilbert J. Immuno-affinity column clean-up with liquid chromatography post column bromination for determination of afflatoxins in peanut butter, pistachio paste, fig paste and paprika powder: Collaborative study. J Assoc Anal Commun Interact 2000;83:320-40.

25. Siddique NA, Mujeeb M, Ahmad S, Panda BP, Makhmoor M. Determination of afflatoxins in medicinal plants by high-performance liquid chromatography-tandem mass spectrometry. J Pharm Sci 2013;16:321-30.

26. Rasheed NM, Gupta VC. Standardization of a compound Unani herbal formulation "Qurs-e-Luk" with modern techniques. Pharmacognosy Res 2010;2:237-41.

27. Wesolowski M, Konieczyriski P. Relation between thermal decomposition of medicinal herbs and their non-metals concentration. J Therm Anal Calorim 1998;54:219-26.

28. Geldart D, Abdullah EC, Hassanpour A, Nwoke LC, Wouters I. Characterization of powder flowability using measurement of angle of repose. China Particuology 2006;4:104-7.

29. En Z, Vasidov A, Tsipin V. Study of element uptake in plants from the soil to assess environmental contamination by toxic elements. Nucl Instrum Methods Phys Res Sec A 2003;505:462-5.

30. Ajasa OM, Bello MO, Ibrahim AO. Heavy trace metals and macronutrients status in herbal plants of Nigeria. Food Chem 2004;85:67-71.

31. Siruguri V, Kumar PU, Raghu P, Rao MV, Sesikeran B, Toteja GS. Aflatoxin contamination in stored rice variety PAU 201 collected from Punjab, India. Indian J Med Res 2012;136:89-97.

32. Kumar KJ, Prasad DAG. Identification and comparison of biomolecules in medicinal plants of Tephrosia tinctoria and Atylosia albicans by using FTIR. Romanian. J Biophys 2011;21:63-7.

33. Keiluweit M, Nico PS, Johnson MG, Kleber M. Dynamic molecular structure of plant biomass-derived black carbon (biochar). Environ Sci Technol 2010;44:1247-53. 